Lund, Anker Brink: Regionalradio i Danmark: Informationsbehov og lokalsamfund. Forskningsrapport nr. 2B/80, DR 1980.

Qvortrup, Lars: "Decentralisering af radiomediet - demokratisering eller legitimation?" Massekultur \& Medier, 2, 1981.

Qvortrup, Lars: Decentralisering af radiomediet i de skandinaviske lande I-V: I: Demokratisering ved hjælp af lokalradio? Decentralisering, provins, urbanisering. II: Lokalradioens programproduktion og programindhold. III: Forsøget med lokal radio- og fjernsynsvirksomhed. Rapport over den danske fors $\varnothing$ gsordnings 1. år. IV: Rapport fra Radio Fyn. V: Rapport fra Radio Gotland. Odense Universitet, 1982.

Regionalradio. Rapport afgivet af det af ministeren for kulturelle anliggender i april 1979 nedsatte udvalg. København 1981.

Simmel, Georg: "Die Grosstädte und das Geistesleben". IN Jahrbuch der Gehestiftung zu Dresden. Band IX. Dresden 1903. Oversat pa Arkitektskolen i Aarhus, Afdelingen for fysisk og økonomisk planlægning.

Svendsen, Erik Nordahl: Regionalradio i Danmark: Lytternes forventninger: Service og debat. Forskningsrapport nr. 3B/80, DR 1980.

Tybjerg, Jette: Danmarks Radios provinsafdeling. Speciale, eget forlag, Arhus 1978.

Zeuthen, Jakob: "Provinsfilosofi"'. Kronik i Kristeligt Dagblad d. 27. november 1981.

Desuden citeres der fra Folketingstidende 1973/74, 1975/76 og 1977/78.

Lars Qvortrup er lektor på Rasmus Rask Instituttet for lingvistik, Odense Universitet. 


\section{REKLAMEN SOM SAMFUNDETS SPEJL OM DET MODERNE SAMFUNDS MORAL OG RELIGION: REKLAMEN}

\section{Af Dominique Bouchet}

Med udgangspunkt i Preben Sepstrups bog Om reklame. En introduktionsbog. ${ }^{1}$ vil jeg forsøge at introducere til en sociologisk forståelse af reklamen. Preben Sepstrup har med $\sin$ bog haft til hensigt "at give laseren et godt all round kendskab til reklamen og dens virkninger." ${ }^{2}$ Jeg vil starte med at give et arligt resumé af bogen for derefter at vise, hvordan kritikken selv kan være en del af det, der kritiseres og kan bekræfte det. Dermed vil der blive introduceret til en mere dybtgående analyse af reklamen som institution. Min tese er, at reklamen ikke salger varer, men varesamfundet, at den er vores tids moral og religion, at den binder vores samfunds forskellige elementer sammen, at den er et bindeled i det samfundsmæssige imaginære, ligesom religionen tidligere har været det.

\section{Resumé af Sepstrups bog:}

Reklamen er en del af den såkaldte markedsføring, den er til for at påkalde opmarksomheden med salg for $\emptyset$ je (kapitel 2). Som massekommunikationsmiddel er den særegen, man kan slukke for radioen, men man kan ikke være fri for reklamer i vores samfund. Reklamen har mange virkninger såvel økonomiske som ikkeфkonomiske på både kort og langt sigt. Eksempelvis er den med til at påvirke både konkurrencen, dvs, erhvervsstrukturen, og individernes værdier og holdninger (kapitel 3). Det er ikke en ny teknik: bogtrykkerkunsten, som er hovedårsagen til reklamens fremkomst, men et bestemt udviklingstrin af konkurrencen, som tvang industrien til selv at påvirke forbrugerne (kapitel 4). Ifølge mange er reklamen til for at skabe kendskab til varerne, den bidrager til hele det фkonomiske kredsløb. Men if $\emptyset$ lge andre mere seriøse analyser er den til, fordi der ikke foregår nogen samfundsmæssig planlægning, og fordi mange varer ikke har særlig nytteværdi: reklamen skal forsøge på at erstatte manglen på reel brugsværdi eller manglen på reelle forskelle i brugsværdier ved at skabe sakkaldte sekundare eller psykologiske brugsvardier (kapitel 5). Men man kan ikke bevise, at der findes en sammenhang 
mellem reklameudgifterne og salget, og den såkaldte 'stordriftsfordel' behøver ikke at resultere $i$ et prisfald. Der findes jo ikke nogen entydig sammenhæng mellem produktionsomkostningerne og prisen, og reklamens fundamentale natur er at øge værdien af produktet ved at gøre market til noget særligt. Reklamen virker i $\emptyset$ vrigt konkurencebegræensende, fordi den styrker præferencen for eksisterende marker. Og man skal ikke lade sig snyde af eventuelle positive virkninger i en virksomhed eller branche, idet det er hele økonomien, som skal tages i betrag tning, når man skal vurdere reklamens virkninger. Det er ikke givet, at for eksempel en større beskæftigelse eller blot en større profit i en branche er til gavn for hele okonomien. Danmark er blandt de otte nationer, som bruger mere end 100 dollars pr. år pr. indbygger til reklamer, og det kan vare dyrt for samfundet (kapitel 6). Halvdelen af reklamebureauerne har internationale forbindelser, og amerikanske virksomheder opkøber stadig danske reklamebureauer (kapitel 7). Reklamen prioriterer forbrug og ting som løsning på alle problemer. Den påvirker os til at bruge vores fritid p̊ måder, som der kan tjenes penge på. Den dyrker respekt for forbruget og ikke for arbejdet. Den fremmer en "køb-og-smid-væk" mentalitet. Den er med til at gøre os mere interesserede $i$ at følge moden end i at være en rar far. Den tenderer mod at gøre os alle ens (kapitel 8).

For virksomheden skal reklamen tjene til at formidle kendskab til varen. Reklamekampagnerne skal være effektive. Man finder derfor det mest brugbare medium for at nå den ønskede målgruppe, idet det jo ikke er alle, som køber hundemad for eksempel. Og man gør meget ud af at finde den rigtige udformning, så ens budskab huskes. Budskabets frekvens overvejes ogsa. Og man forsøger at måle effekten af kampagnen bagef ter (kapitel 9).

For det enkelte menneske betyder mødet med den enkelte annonce en påvirkning, som ikke behøver at være bevidst. Hver enkelt frasorterer og tolker, glemmer noget, husker noget andet. Og annoncørerne gør, hvad de kan for at kontrollere disse bevidsthedsmekanismer (kapitel 10).

For massemedierne er reklamen en indtæg tskilde. Aviserne ville vare dyrere, hvis de ikke brag te disse annoncer, som i gennemsnit fylder en tredjedel af avisen. Men reklamen betyder også noget for mediestrukturen. Saledes er specialbladene blevet styrket af reklamepengene, fordi de bedre rammer bestemte målgrupper, mens de 
socialdemokratiske aviser har mattet bukke under, fordi deres læsere var mindre købedygtige og på grund af politiske holdninger hos annoncørerne. Et helt nyt massemedie er også dukket op: annonceaviserne, som uddeles gratis. Reklamen betyder også noget for mediernes indhold. Eksempelvis kan det næunes, at de mange tillæg er blevet skabt af aviserne for at skabe bedre redaktionelle miljøer til annoncerne. Og enhver har svært ved i ugebladene at skelne mellem, hvad der er reklame, og hvad der ikke er det (kapitel 11). Der findes ogsa flere og flere reklametryksager. Vi fär i gennemsnit over 300 af dem igennem brevsprækken hvert år. Nogle får endnu flere, idet de står i særlige kartoteker. Nogle ønsker at blive fri for dem, fordi de kan vare til stor irritation (kapitel 13).

For fjernsynets vedkommende vil indførelsen af reklamen ikke betyde en gratis ekstra kanal, men snarere en omfordeling af reklamens penge, som vil fả betydelige konsekvenser for de øvrige medier, (særligt for dem, som tidligere trykkede netop disse reklamer som nu vil blive sendt ( TV) samt resultere i en $\emptyset$ get koncentration og monopolisering (idet det kun bliver dem, som salger landet over, som vil vare i stand til at sende deres annonce i TV). Især udenlandske kapitalstærke virksomheder vil have gavn af reklame-TV. Det er derfor ikke så sikkert, at det danske erhvervsliv burde støtte projektet. For seerne kan det betyde en alvorlig kvalitativ andring, idet man, for at kunne skabe et gunstigt miljø for annoncørerne, vil sende programmer, som får de fleste til at kikke på skærmen, og som gør dem modtagelige for annoncørernes budskaber. Desuden vil det $\emptyset g$ e den generelle brug af tid på at se TV. Nogle påstår, at man skal skynde sig at etablere et dansk reklame-TV, inden satellitterne gør det muligt for alle danskere at modtage andre landes reklamer; men andre hævder, at man overdriver disse modtagelsesmuligheder, idet sprogproblemer og antenneomkostninger nok vil dæmpe udbyttet. Og det er tvivlsomt, om eventuelle uheldige virkninger af udenlandsk reklame-TV bedst imødegås gennem oprettelse af et dansk reklame-TV (kapitel 12).

Reklamerne indeholder meget lidt information, fordi de ikke er til for at tydeliggøre, at alle produkterne er temmelig ens, men for at gøre dem forskellige ved at knytte forskellige værdier ("images") til dem. Reklamen skal heller ikke erindre én om besværligheder (som eksempelvis betalingen eller brugen af bestemte varer), men fremkalde lysten til tilegnelse. Forbrugerne har krav pa en meget større oplysningsvardi i reklamen, og dette kunne påbydes ved lov. Reklamerne 
indeholder til gengæld megen ideologi. Borgerlige dyder og idealer og fremherskende vardier knyttes til varerne. Reklamen støtter etablerede værdier og skaber meget sjældent nye. I reklamernes verden er alle unge. De befinder sig hjemme eller i naturen, men ikke på arbejdspladsen eller $i$ byen. Vi presenteres for en ideel og problemfri verden, som er med til at skabe vores opfattelse af, hvad der er vigtigt, og hvad der er normalt (kapitel 15). Reklamerne fortæller os, at kvindernes plads er i hjemmet: Der vises således mange færre udearbejdende kvinder i reklamerne, end der faktisk er i forhold til mand. Kvinderne i reklamerne er gennemsnitligt unge og mere passive end mand i reklamerne og kvinder $i$ det virkelige liv. Kvinden er i mange tilfalde blot en pyntegenstand. Reklamen er således kønsdiskriminerende. Den er ikke årsag til de grundlaggende kønsroller, men den benytter sig af dem, og der er faktisk mange, som synes, det er for dårligt (kapitel 16). Mange reklamer appellerer til vores sexualitet ved hjælp af mere eller mindre skjult symbolik, og der findes mange fallos-symboler på de plakater, som kan ses overalt (kapitel 17). Vi udsættes alle for reklamens påvirkning, og dette indvirker også på vores omgivelser, som får et særligt udseende, som adskiller sig eksempelvis fra det, man kan opleve i $\varnothing$ steuropas byer (kapitel 18). Vi bliver selv barere af reklamer, idet vi render rundt med $t ø j$ med tydelige mærkenavne. Reklamer kan endda blive legetøj: Vores børn leger huskespil med varemærker (kapitel 19).

Bogen afsluttes med en præsentation af de juridiske rammer for reklamen (kapitel 20), nogle konkrete forslag til regulering af den samt overvejelser over reklamekritikkens nytte (kapitel 21 og 22) og ideer til brug for at analysere de reklamer, man udsættes for (kapitel 23). Den er forsynet med en bibliografi, et stikordsregister samt en præsentation af det internationale reklamekodeks som bilag.

\section{Hinsides bogen henimod en radikal analyse}

Ifølge Preben Sepstrup fungerer reklamen ikke efter sin erklæerede hensigt. Den er ikke oplysende. Den får ikke priserne til at falde. Den sikrer ikke konkurrencen. Den skaber ikke større beskæftigelse, bedre produkter, god planlægning og bedre фkonomi for nationen. Den sikrer ikke den enkelte borgers valgfrihed. Tvartimod tranger reklamen mere og mere ind i vores privatliv, den forsøger at påvirke os, 
uden at vi selv lagger marke til det, og den kan endda skabe falske behov. Reklamen fungerer ogsa som et pres på det politiske system, idet den er med til at bestemme over de $\phi v r i g e$ mediers indhold og storrelse, idet den gør os mindre interesserede i alt det, som ikke er forbrug, og idet den formidler borgerlige vardier. Den invaderer vores fritid, far os til at glemme arbejdet og den kamp, der skal føres der, og den undertrykker kvinderne og stotter konformismen.

Kort sagt mener Sepstrup, at reklamen ikke er rationel nok (blandt andet i forhold til den фkonomiske planlagning), men at den er konservativ og bedragerisk. Selvom et sådant synspunkt indskriver sig radikalt imod den herskende offentlige opfattelse blandt erhvervsfolkene, og selvom det er nogenlunde velargumenteret, $\$ a$ er det ikke af den grund nødvendigvis et radikalt synspunkt.

\section{Et moment i andringsprocesserne}

En hel del af bogen bygger pa Sepstrups forskning om reklamens diskrimination af kvinder. Han har optalt de mange halvnøgne kvinder pa plakaterne og har konstateret, at de langt overstiger antallet af nogne mand, og at de endda langt overstiger antallet af halvnogne kvinder, der i virkeligheden findes i gaderne, Man kan starte med at spørge sig selv, hvorfor reklamen skulle give en korrekt afspejling af det virkelige liv.

I sa fald skulle over $30 \%$ af reklamerne vise sovende mennesker. De skulle ogsa vise dårligt betalte kvinder på arbejdspladserne. Preben Sepstrup kunne have brugt sin konstatering af, at reklamen faktisk ikke er et agte spejl, til at gøre opmarksom pa hvilken type spejl reklamen faktisk er. Men han har blot brugt konstateringen til at angribe reklamen for at vare kønsdiskriminerende og konservativ.

P\& side 22 far vi at vide, at allerede omkring arhundredskiftet begyndte man at anvende den kvindelige skфnhed som et argument i sig selv i reklamerne. Men vi far ikke noget narmere at vide om, hvorfor skønheden kan anvendes, og hvorfor det netop er den type skønhed. (Jeg vil senere her antyde, at det kan vare fordi reklamen vil gore os alle til fetichister og flytte vores begar andetsteds hen). I det gamle Grakenland, og $\mathrm{i}$ andre civilisationer, pyntede man visse steder og ting med 
menneskelige skønheder, men Sepstrup forklarer os ikke, hvad forskellen var. Som det vil fremgd̊ af artiklen, er der én, og den er afslørende for reklamens funktion. Samtidigt har alle disse skønheder, som pynter vore museer, noget til fælles med vor tids reklamer. Når vi tænker på, at reklamen efterhånden er den eneste institution, hvor kunstnere i dag kan få penge for deres præstationer, kan det minde os om, at kunstnerne tidligere malede for kirken og for aristokraterne. Jeg antyder her, at trods det, at reklamen faktisk opstod som salgsmiddel, kan den have en funktion, som rakker langt ud over salgspropaganda. Jeg antyder, at reklamen har overtaget noget, som ikke var specifikt for kapitalismen og har gjort det til noget særligt.

Lige så lidt som reklamen har skabt vores brug af billeder, lige så lidt har den skabt det kvindebillede, som stadig hersker. Det er ikke reklamen som har fået kvinderne til at føle sig urene. Det er ikke reklamen, som gør, at kvinderne skal vaske sig hele tiden, få tøj til at blive mere hvidt, udsmykke sig, skjule deres menstruationsbind $\mathrm{m} . \mathrm{m}$. Reklamen har ikke skabt dette kvindebillede, kapitalismen heller ikke. Reklamen har været med til at formidle billedet, men den er hverken blot et spejl eller en "reaktionar" kraft.

Som de фvrige medier har reklamen en "ekko-funktion" ("konservatisme"), men den fanger også nye ideer og livsmåder, den filtrerer (vælger nogen), og kan endda forstarke nogle tendenser. Kort sagt, den er et moment $\mathrm{i}$ andringsprocesserne i vores samfund. Det er sandt, at der ikke findes mange rødstrømper eller æeldre damer på plakaterne, men tallene siger os ikke ret meget om, hvor meget reklamen bidrager til, eller bekæmper kvindefrigørelsen. Det kan være, at reklamen bidrager meget mere til andringer i socialiseringen end den opdragelse, hvor forældrene som regel blot reproducerer det, de selv er blevet udsat for tredive år tidligere. En enkelt afvigende reklame kan have en meget større effekt end alle de sædvanlige. Og det ved annoncørerne, når de til bestemte produkter eller til bestemte formăl viser grimme kvinder eller mænd, som er ved at lave det, som stadig betragtes for at vare en kvindelig opgave, eller kvinder som reparerer deres knallert selv ...

Når Preben Sepstrup gør så lidt ud af at se på ændringerne, som han selv har været med til at undersøge (s. 138), kan det måske skyldes, at han på forhånd mener, at reklamen er konservativ (s. 118). Men reklame er ikke propaganda. Propagandaen 
henviser som regel til et dogme, og tager ikke hensyn til tilhørerkredsen. (Det er politikken, som er demagogisk, ikke propagandaen. Men jeg vil her senere konkludere mod en ophævelse af alle disse forskelle). Reklamen er faktisk interesseret i feed-back, og er derved meget mere dynamisk. Den behøver derfor ikke at være "konservativ". Det er i фurigt ikke let at skelne mellem det, som bekræfter den etablerede orden, og det, som peger mod et alternativ. Endringerne kan vare et element $\mathrm{i}$ den udviklingslogik, som findes indenfor den etablereder orden, og det kan vare en del af denne logik at pege pa et alternativ. Eksempelvis er det ikke oplagt, at kvindernes plads i vores samfund skal forblive den samme. Det kan også godt være, at en statslig overtagelse af opdragelsen tjener mere til selvstændigg $\varnothing-$ relsen af vores $\emptyset$ konomiske system end til vores fælles velvære. En eventuel tvetydighed burde gøres til genstand for opmærksomhed.

\section{Funktionalismens begransninger}

Man kan ikke kræve af en introduktionsbog, at den belyser tvetydigheden 1 det sociale; men man kan kræve, at forfatteren gør sine forudsæ tninger klare, og ikke bidrager til bekræftelsen af en forenklet forestilling om det sociale. Skulle det virkeligt, som Preben Sepstrup foreslår, være så "progressivt" at afspejle virkeligheden mere nøje? Skulle det være bedre med en reklame, som er mere funktionel? En reklame som fortaller mere om det, som vi tror er produkternes egenskaber?

Der gøres i kapitel 19 opmærksom på, at folk nu bærer rundt p§̊ et mærkenawn eller et mærkesymbol og derved annoncerer gratis; at det faktisk i dag "kræver en aktiv og ret stor indsats ikke at gå rundt som en levende reklamesøjle." ${ }^{3}$ Skulle det være bedre, hvis man fik penge for det? Er det ikke bemærkelsesværdigt, at der er sa mange aktivister, som bærer rund $\mathrm{p}$ p̊̊ politiske reklamer eller idoler? Er politikken ved at blive reklame? Eller hvad?

Når forfatteren på side 53 synes at mene, at det er for dårligt, at der ikke findes nok annoncer for kollektiv transport og genbrug, om risikoen for lungekræeft og adfærd i trafikken, så kan man spørge sig selv, om denne konstaterede skæeve fordeling har så meget med reklamens natur at gøre, eller om det er et tidsbegrænset fænomen, en fase som reklamen takket være sin funktion snart vil 
ændre på. De efterlyste reklamer orn kollektive anliggender er faktisk i stor udvikling. Der reklameres for trafikken i TV og radio. At man nu reklamerer for Folkekirkens Nødhjælp på banegårdene behøver ikke at være noget, man skal glæde sig over.

\section{Arbejde og forbrug}

At reklamen formidler fordrejede billeder af arbejdsforholdene behøver ikke at betyde, at reklamefolkene er betalt for at f⿱乛龰 os til at glemme det kedelige arbejde. Og hvis det forholdt sig sådan, var det ikke givet, at det var arbejdsgiverne, som ønskede at sende sådan et billede; det kunne måske være arbejderne, som ønskede sig det. Når forfatteren (s. 89) păstår, at aviseme ikke handler så meget om arbejdsforholdene, fordi de ikke vil genere deres annoncører, så kan man lige så godt havde, at det er fordi, hele samfundet har et tvetydigt forhold til arbejdet. Når aviserne ikke skriver så meget om det, behøver det ikke at være for at undgå at komme "p̊̊ tværs af annoncørernes formå og samfundssystem"; det kan lige så godt vare for avisernes eget formal og for lasernes samfundssyn, eller for et formal, som er fælles for alle medier, men som ikke behøver at have direkte med annonc $\varnothing$ rernes interesse at gøre.

Når reklamen handler om forbrug og ikke om arbejde, kan det selvfølgelig skyldes, at man sjeldent forbruger, når man arbejder. $10 \mathrm{~g}$ der findes mange specialreklamer, som vedrører forskellige arbejdsfunktioner, og som i mange tilfalde er meget mere tekniske og oplysende end dem, Sepstrup nøjes med at analysere). Men det behøver ikke være énsbetydende med, at reklamen, som forfatteren synes at mene, ikke har med arbejdet at gøre. Man kunne lige så vel sige, at reklamen er til for at salge arbejdet. Det er tit forbrugsdrømmen, som lukker de unge ud pa arbejdspladserne, og man kan spфrge sig selv, om mindre reklame ikke ville forårsage større sфgning på universiteterne og højskolerne.

I фvrigt, forholder det sig virkeligt sådan, at "mange mennesker oplever kun at udfolde sig og oplever kun respekt gennem forbruget - og ikke gennem f.eks. arbejdet"? ${ }^{4}$ Skulle det vare bedre at betragte arbejdet som det mest positive i tilværelsen? Findes der ikke mange tilfælde, hvor den prestige, man høster ved at 
udføre en bestemt funktion på arbejdspladsen, tvinger én ind i et bestemt forbrugsmønster?

Handler reklamen virkeligt om at omsatte utilfredshed til forbrug? (s. 136). Er det virkelig klasseinteresser, som reklamen formidler? Er det virkeligt sandt, at "kun klasseforskelle og ikke klassemodsætninger kommer til udtryk i forbruget"? (s. 176). Det er jo et kæmpeprivilegium at kunne disponere over sin tid, og måske er det et lige så stort privilegium at kunne forstå reklamerne og analysere dem. Handler reklamen ikke om magt? Støtter den ikke nogle menneskers fri bevægelighed, samtidig med at den forhindrer andres autonomi? Eller er det reklamen, som er det eneste, som er autonomt nu? Er reklamen "først og fremmest et overfladefænomen"? ${ }^{5}$ Kan man skrive, at den er "en afspejling"? 6

Alle disse spørgsmal forbliver ubesvarede af Preben Sepstrup. Og hvad værre er, de er ikke stillet. Analysen bliver derved overfladisk og dybt påirket af forfatterens manglende bevidsthed om disse problemer. Det er nemlig vigtigt at gøre sig klart, at mystifikationen kan findes i måden at stille spørgsmålene pa.

\section{Metodemassige falder}

Forfatteren har valgt at anvende positivistiske kvantitative metoder. Tilsyneladende har han fundet det nødvendigt at tale og måle på samme måde, som han har lart det $p a ̊$ handelshøjskolen. $\mathrm{Vi}$ har lige antydet, at antallet af nøgne kvinder i reklamerne intet siger os om, hvordan kvinderne ser sig selv i reklamerne, ikke siger os meget om, hvorvidt mændene er ved at andre deres forhold til piger, ikke oplyser os om, hvorvidt reklamen skaber frustrationer eller selvtilid. Men Sepstrup anvender den samme metode til at analysere mange andre aspekter end kønsdiskrimineringen.

Ps side 46 bringer forfatteren en tabel over "reklameomkostningerne" i forskellige lande. Bortset fra at han glemmer at fortælle os, hvordan det kan være, at Danmark if og det er jo noget, som ikke så let kan erfares, når man rejser på interrail, og bortset fra at han glemmer at gøre os opmarksom pa, at reklamernes indhold og 
fordeling pr. produkt i disse forskellige lande er forbavsende ens, når man tager i betragtning, at de samme landes forbrugsstrukturer er sa forskellige - man gar for eksempel meget mere op I møbler i Danmark end i Frankrig - sa glemmer han at bemarke, at disse tal faktisk er ret intetsigende. Priserne pa de forskellige medier (for eksempel) behфver ikke at reflektere en faktisk effektivitetsforskel. Bag ved hver brugt dollar skjules der saledes mange forskellige reklame-vardier. Hvem kan satte $x$ linier i Stiftstidende lig med y minutter i fransk TV? Og det kan vare, at man visse steder har for vane at investere mange flere penge i favorpriser til grossister eller forhandlere end i reklamen.

Reklameaktiviteten i en bestemt sektor er jo afhengig af mange faktorer sa som: 1) den andel, som i denne sektor salges som markevarer, 2) konkurrenceintensiteten, 3) købefrekvensen (hver enkelt forbruger køber flere stykker sabe end parfumeflasker), 4) innovationsrytmen i denne sektor, 5) den form for markedsf $\phi$ ring, som normalt anvendes i sektoren. Saledes kan reklameudgifterne forklares med markefanomenet, innovationsrytmens acceleration, reklameteknikkernes stadig mere raffinerede og kostbare metoder, men det kan vare, at man ikke har forklaret så meget med det ... Hvordan kan det vare, at der i de lleste industrialiserede lande bruges nasten lige sa mange penge til reklamer, som der bruges til uddannelse? at der anvendes mindst lige sa mange kvalifikationer, mindst lige så mange arbejdstimer? Hvor er årsagerne, og hvor er virkningerne?

For mig at se, er det faktisk mere interessant, at man absolut skal male reklamens effektivitet ved hjelp af disse statistisk prisfeticherede metoder, end hvad disse tabeller kan fa os til at tanke på af mulige korrelationer (som for eksempel at alle katolske lande bruger langt mindre penge på reklamen end de protestantiske).

Det forekommer nu, at Sepstrup har for stor respekt for de metoder, som anvendes i hans forskningskredse. 7 Statistikkerne siger os ikke ret meget om reklamens funktion, og dette selvom de antyder, at der ikke findes en direkte sammenhang mellem reklameudgif terne og salg eller profit. Mange andre faktorer kan spille ind. Statistikkerne siger os ikke ret meget om hvilke faktorer der her har haft indflydelse pa salget. Og reklameudgifterne kan skyldes noget, som ikke har ret meget med salgsfremgangen at gøre. Eksempelvis kan mund-til-øre-metoden, en konkurrents markedsforing, vejret, de udsendte verdensnyheder i TV, ... betyde 
meget, når et nyt produkt skal på markedet. De konstaterede relationer eller korrelationer behфver heller ikke skyldes reklame-udgifternes indflydelse p\& salget, de kan lige sa meget skyldes salgets indflydelse pa reklame-udgifterne. Det er blevet påvist af Joachim Marcus-Steiff ${ }^{8}$, at de store reklameudgifter i mange tilfielde har efterfulgt de store salg af eget produkt eller af en konkurrents produkt, dvs. at det tit forholder sig omvendt af, hvad mange tror. Der findes ogsa mange eksempler $\mathrm{pa}^{\mathbf{s}}$, at reklameudgifterne ikke har resulteret i en ekstraprofit. Desuden er det bemarkelsesvardigt, at de fejl, som man finder i de artikler, som behandler problemet p\& grundlag af statistisk materiale, alle kommer reklamens effektivitet til gode. Joachim Marcus-Steiff har afsløret, at mange har benyttet sig af meget indviklede teknikker for at komme til en falsk konklusion. Dette kan tyde på, at der hos disse statistikere findes en forudfattet mening, som deres statistiske metode ikke kan hjelpe dem af med. Og denne fordom kan vare interessant i sig selv. I stedet for a bruge så mange sider på at gentage intetsigende statistiske unders $\emptyset$ gelser og dermed reklamere s\& meget for pseudo-videnskabeligheden, kunne forfatteren have undret sig over, at markedsforingsfolkene faktisk valger metoder, som kommer reklamen til gode. Eksempelvis navner han, at de maler effektiviteter af deres kampagner ved hjelp af interviews (s. 71). Om man har set annoncen og kan huske den, siger jo ikke meget om, hvad man vil købe. At mange nøjes med sådanne undersøgelser kan skyldes, at det hele ikke er sa rationelt som Sepstrup antyder. F.eks. kan det vare, at handelsfolkenes forestillinger og mentalitet inciterer dem til at lave en masse reklame, som måske ikke er så effektiv, som de tror, men som de godt kan lide... Hvordan kan det vare, at man ikke laver interviews med dem, som bestiller kampagnen? Der findes mange VVS mand som takket vare reklamen kan se deres navn skrevet overalt. Det kan godt være at reklamen ogsa er til for firmaernes identitetsbillede indadtil, og ikke kun for at danne et image udadtil. Det kan godt være, at det er managerne, som har brug for reklamen for ders eget image over for sig selv eller over for deres kolleger. Reklameforbrug er måske mere et statussymbol, end et rentabelt salgsmiddel.

Annoncørerne kender faktisk ikke deres reklameudgifters reelle rentabilitet. Den bedste måde, man har fundet $p^{\mathfrak{a}}$ at studere den, er at anvende forskellige strategier i forskellige regioner, når dette kan lade sig gøre. Salget måles i forretningerne og ikke ved at sporge forbrugerne. Selvom en potentiel forbruger har set en reklame, kan det vise sig, at han køber konkurrentens vare, nar han 
møder op i forretningen. Det kan skyldes en særlig reklamestrategi fra konkurrenten p\& salgsstedet. Det sker tit at en person, som møder op for at købe X, køber $Y$ på grund af salgsstedets organisering. (Tilbud, opstilling, reklamer, ..). Der anvendes de største reklamebudgetter der, hvor produkterne er mere ens, (benzin, elektriske apparater, vaskemidler, farmaceutiske produkter, parfumeprodukter, ....) men jo mere ens produkterne er, jo mindre stabile er købsintentionerne, og det ved

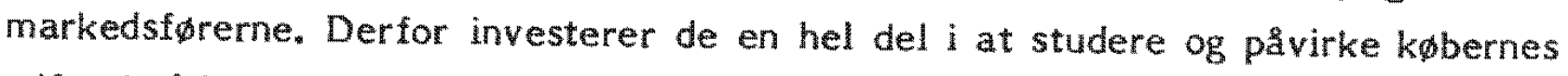
adfærd på indkøbsstederne.

\section{Forfarelsesteknikker}

Preben Sepstrup nævner ikke, at ca. halvdelen af markedsføringsbudgetterne tildeles sales-promotion, at supermarkedernes miljø har deres egen dynamik, og at reklamen og andre salgsteknikker også fungerer der, og måske på en lidt andet måde end ikonerne i bladene.

Forførelsesteknikker har reklamen ingen monopol pđ̊. Et besøg i et indk $\emptyset b s c e n t e r$ uden $k \phi b$ for $\emptyset j$ e og med lidt sociologisk kendskab kan afsløre en del. Lyset og lyden skaber en særlig atmosfære. Købernes vandringsrute synes at være planlagt. Først til højre, hvor man skal hente en indkøbsvogn, som kan rumme 170 liter, madvarerne finder man ca. midt $p \AA$ vejen og de dyreste varer møder man til sidst (hvis man alts\& ikke er kommet ef ter dem) sammen med bolsjer og plastic-smykker. Visse varer er opstillet i tilsynedeladende uorden, andre er placeret i mærkværdige højder. Til tider kan afstanden mellem de opstillede varer variere. Ja endda gulvets niveau kan nogle gange variere, uden at man kan se en arkitektonisk nødvendighed $\mathrm{i}$ det. Alt kan vi røre ved. Vi er fri for disse ekspeditricer, som kan gøre os reserverede. En stemme kan også opfordre os til at benytte os af et tilbud. Mange plakater reklamerer for disse tilbud, sorn ikke behøver at være særlig fordelagtige, men som giver os god samvittighed over at købe. Og hvis vores gode samvittighed forsvinder senere hen ad vejen, kraves der en stor indsats for at finde varen under alle de $\phi v r i g e$, som nu fylder indk $\phi b s v o g n e n$, for derefter at finde tilbage til det sted, hvor man blev fanget af den.

Salgsteknikere har $\mathrm{i}$ de sidste fyrre år studeret forbrugernes adfærd, og dette har 
for eksempel resulteret I viden om, hvor stort et antal af bestemte varer man skal opstille for at opnd det storst mulige salg, eller i bestemte valg af farvesammensætninger på etikketter af produkter, som appellerer til bestemte typer mennesker (eksempelvis på whisky-flaskerne og vaskepulverkartoner). Solgte psykologer leger stadig i dag med eksperimenter som for eksempel at komme det samme vaskepulver i tre forskellige emballager til udvalgte husmødre for at finde ud af, hvilken emballage der får disse til at tro, at deres vasketoj er endnu mere hvidt end hvidt. Skjulte kameraer eller solgte etologer undersøger menneskenes købeadfard i salgsreservater for at tilpasse miljøet endnu bedre til dem. Solgte økonomer regner ud, hvor meget en bestemt genstand skal salges for for at give den storst mulige profit, mens andre sфrger for, at nogle kan føle, at de for fa penge far noget, som ser dyrt ud. Nye fiduser bliver anvendt, nar motivationsforskningen har gjort det muligt, eller når tiderne har andret sig. Eksempelvis kan man navne alle disse "naturlige" "hjemmelavede" produkter, alle disse etiketter med masser af oplysninger, som nu dukker op, og som så få mennesker laser eller forstå, men som giver os mere tillid. Og det siges at vi har brug for "tillid" i en krisetid.

Nogle påstår, at disse teknikker ikke anvendes i Danmark. Men selvom der ikke fandtes en eneste markedsf $\varnothing$ ringsagent, som selv studerede disse manipulationsteknikker, reproducerer de alle disse salgsmønstre. Man behøver ikke selv at have opfundet den nye tallerken, når man har set én i USA eller et andet sted. Selv den lokale købmand ved nu narmest intuitivt, at der skal lidt musik til, at bolsjerne skal vere ved kasseapparaterne, og selvom han selv er overbevist om, at han spiller lidt musik for sig selv, og at bolsjerne skal vere der for ikke at blive stjalet, har han faktisk lart af al den motivationsforskning, som han ikke selv har ivarksat.

\section{Kritikkens elendighed}

Man kan derfor ikke imødekomme den form for kritik, som Sepstrups bog er blevet udsat for:at "bogen nermer sig visse steder den rene fiktion, hvor forfatteren helt klart lagger meget mere vagt pa de dybepsykologiske aspekter, end reklamefolkene nogensinde har tilsigtet." 9 Berlingske Tidende ${ }^{10}$ angribes Sepstrup for at se sexsymboler over alt. I Fyens Stiftstidende 11 "smiler (man) af hans argumenter" fordi "bogen undervurderer groft både annoncorer og forbrugere, De forste ved 
godt, at reklamer uden reel oplysning ikke er meget værd. Og de sidste tager de reklamer med det fornødne korn salt, som fortæller, at den hvide tornado klarer rengøringen."

At der stadig findes nogle naive anmeldere, som tror, at det er Sepstrup, som er mytoman eller endda erotoman, kan ikke undre dem, som sætter forståelsen foran forvaltningen. Men den slags bemærkninger skal kritiseres. Som sagt, selvom der ikke var nogen, som var betalt for, ved hjelp af teori, at finde vejen til køberens underbevidsthed -og de er legio - kunne denne vej findes ved hjælp af empiriske unders $\varnothing$ gelser, ved blot at prøve sig frem til den type billede som giver de bedste resultater, uden selv at ane hvorfor det virker. At der stadig findes nogle samfundsmedlemmer, som ikke aner, at mennesker fylder verden med symboler, vil ikke ændre det faktum. ( $\mathrm{P}$ s side 72 bemarker forfatteren, at der ikke findes malinger af de effekter en annonce matte have pa det ubevidste plan, at der ikke findes mallinger af effekten af flere påvirkninger eller af de langsigtede effekter i forhold til individet. Reklamefolkene behøver ikke at male den slags, de benytter de pa side 70 omtalte før-tests, og det kan de gøre, uden at de faktisk behøver at forstå, hvad der sker. For samfundsvidenskabsmændene er det netop forståelsen, det handler om, men hvem siger, at den kan opnås ved hjælp af mallinger?) Man kunne endda tilføje, at det godt kan være, at de reklamebureauer, som arbejder med Freuds beskrivelse af kvindernes underbevidsthed, tager fejl; at kvinderne ingen penis-misundelse kender; men de er under alle omstændigheder med til at skabe symboler. P\&standen om at vi allesammen er voksne og ikke tror på alt det, som reklamen vil bilde os ind, kan man ogs̊ acceptere. Men man skal huske 1. at reklamen ikke kun handler om at salge den enkelte vare, som der annonceres med, 2. at vores born ikke er voksne.

\section{Bøm og voksne}

Bogen indeholder et kapitel om kvinderne. Hvorfor ikke et om bømene? Hvis børnene, trods reklamerne, stadig skulle vare i stand til at anvende rationelle overvejelser, når de skal handle, skulle det derfor betyde, at de ikke er blevet påvirket af alle disse reklamer, som er med til at socialisere dem? Det kan godt være, at nogle reklamer kan annullere andre med hensyn til lysten til at købe de 
omtalte produkter. Men hver enkelt reklame bekræfter alle de andre.

Bornene har endnu mere svært ved at skelne, idet 1. de ikke har fulgt med udviklingen i reklamen, 2. alt er gjort for, at de ikke skal kunne skelne. Således er TV-helten gjort til sælger. I Danmark optræeder Anders And og Muppeterne pa mange emballager, og de tyske børneudsendelsers dukker sælges til reklamebranchen for mange penge. Også formen skaber forvirring. Reklamerne ligner borneudsendelser. Mellem TV-reklamerne sender man sjove tegneserier...s

Mår man laver analyser af reklamens virkning på børnene, kan man således ikke nфjes med at se, hvorvidt børnene kan skelne mellem de enkelte produkter, hvorvidt de analyserer kritisk eller ej, ikke tror på alt det ros, osv. ...., man skal også se, om de køber normen: at man skal købe for at være. Man skal studere, hvilket billede børnene modtager af verden.

At de voksne synes at være meget mere barnag tige (i den gode betydning af ordet) i reklamerne end i livet behøver ikke at være negativt. Og dog? I de fleste TVreklamer jeg har set - og der er mange i Danmark, som også har set dem - er en voksen en "barnagtig" forbruger, som savner sin barndom, leger voksen en gang imellem, betragter verden uden ansvar og tilbringer sit liv med at efterstræbe en livsmåde. Disse voksne beundrer som regel børnene, som også leger børn. Via reklamen opfordres salledes børnene til at mime deres alders stereotyper, til at vare små narcissister allesammen. De får at vide, at det at være voksen består i at kunne forbruge endnu mere, at forbrug er livsglede, at der ingen indsats kræves men blot $k \emptyset b, . .$. Det kan være at skolelæreren fortæller dem noget andet, men kan man være sikker på at de hører mere pa ham? Og den dag disse børn skal vælge personlighed, kan man da vare sikker på, at de vælger andet end narkotika? Og hvis det viser sig, at det ikke er så nemt det hele, skulle man da undre sig over, at nogle valger de endnu hårdere stoffer, eller kriminaliteten?

\section{Angst og misundelse}

De reklamefolk, jeg kender, har en meget større viden om og forståelse af det, de foretager sig end disse anmeldeldere, som ikke analyserer deres foragt og forargel- 
se. Men Sepstrup synes ikke at have mødt andre end nogle fuldstiendig ukritiske marionetter. "Den almindelige forklaring på reklamen", som man finder i bogen, hentes fra reklame-branchens propagandamateriale igennem forfatterens lyst til at latterliggøre de onde. ${ }^{12}$ Der er tale om en karrikatur. Det var ellers et meget vigtigt emne, og det kunne have tjent bogen at levere en mere nuanceret og kritisk præsentation af de menneskegrupper, som bærer reklamen. ${ }^{13}$

Alternativet til den "almindelige forklaring" er ifølge forfatteren en kritisk forklaring, som kan enten være marxistisk eller à la Galbraith. Den marxistiske forklaring er også meget forenklet og yderst interessant. Reklamen skulle tjene til erstatning for planlægningen (s. 29). Forfatteren glemmer at bemærke, at der hvor 5-årsplanerne hersker, anvendes reklamen til at rette på planlægningens fejltagelser eller fejltrin. Jeg finder argumentationen besynderlig. Hvis forfatteren havde skrevet, at planlægningen kan spare os mange uproduktive omkostninger i cirkulationssfaren, (og det er en udgave af det marxistiske forvaltningsargument), ville jeg bedre kunne acceptere den selvom man kan sige at rentabilitetskravet er kapitalistisk. Det er sandt, at konkurrencen skaber reklamen (s. 80), men det er ikke så sikkert, at det omvendte ikke er lige så historisk rigtigt. ${ }^{14}$ Det afhænger selvfølgelig af, om man definerer reklamen på forhånd, som forfatteren faktisk gør, eller om man prøver at forstå fanomenet uden at låse sig fast p§̊ en af dets fremtradelsesformer. Det, som vi i den samfundsmæssige diskurs kalder "reklamen", sagt på en anden måde: det, som dem, som ikke har udviklet et kritisk begrebsapparat, kalder reklamen, kan være toppen af isbjerget eller den form, som den har under de nuværende atmosfariske forhold.

Reklamen kan ikke forklares blot med en henvisning til udbytningslogikken i det kapitalistiske system, som nu trænger ind p̊ fritidsområdet. Det er sandt, at reklamen blev til, da det kapitalistiske system fandt det nødvendigt at planlægge hele det menneskelige liv, da det blev klart, at den kapitalistiske produktion ikke blot krævede en bestemt type arbejdsorganisering, men ogsa en bestemt måde at bruge fritiden p\&. Som en stormagasinmagnat i Boston udtrykte det i 1919: "Masserne må lære at opføre sig som mennesker i en masseproduktionsverden". Men kapitalismen er netop massesamfundet. Et samfund, fortalte Tocqueville, hvor enhver, pr. samfundsdefinition, skal have travlt med at finde sin status, hvor angsten institueres og benyttes til pengejagten og kapitalakkumulation. Reklamen 
kan således være det, som erstatter religionen i et samfund, hvor man ikke skal blive pa sin plads og vente, men hele tiden forsøge at vare en anden, som de andre selv kunne tæenke sig at være. Reklamen er de statussøgende folks religion. "Reklame institutionaliserer misundelsen og den angst, der hører med hertil." skriver Christopher Lasch. ${ }^{15}$

Reklamen formidler misundelsessystemet $\mathrm{i}$ et samfund, hvor den instituerede "lighed" sender alle ud i krig mod sig selv og alle de andre. Reklamerne er spejle, som fortæller os, at vi kan opnå større status. Reklamen forfører ved at gøre én misundelig, ikke på en anden, men på én selv, ikke som man er i dag, da det blot ville være selvtilltedsstillelse, men som man kan blive i morgen, hvis man kører med på racet. Reklamen har ikke ret meget med attrå at gøre; attråen er et forhold til ting. Reklamen skaber den narcissistiske misundelse; misundelsen er et forhold mellem mennesker. Reklamen handler mere om sociale forhold end om ting, men denne misundelse er ikke blot narcissistisk; den handler om at misunde sig selv, som én der kan blive misundt; reklamen er skuespilagtig, den opfordrer til rollespil og upersonlighed. Reklamen er bureaukratiprincippet udvidet til enhver. Eller som John Berger skriver det "Reklamebilledet stjæler hendes kærlighed til sig selv som hun er, og sælger det tilbage til hende for prisen pa produktet." 16 men samtidigt har hun tabt en hel del muligheder for selv at kommunikere: nu er hun selv en del af reklameverdenen. Stakkels Alice, som kikker sig selv i spejlet, men som selv er blevet et spejl. Reklamen er spejlene i uendelighed. Stiller man et spejl op mod et spejl, da vil billedserien blive uendelig, og den spejlede genstand vil opfatte sig selv om et af sine spejlbilleder. Hermed installeres et uendeligt begar, der opløser subjektets evne til at identificere objektverdenen og betingelserne for dets egen tilegnelse af den.

John Berger gør opmarksom på, at reklamen er "forbruger-samfundets kultur", at den ved hjælp af billeder udbreder "samfundets tro på sig selv". Han analyserer forskellene mellem vor tids reklamebilleder og fortidens oliemalerier, og bemarker at oliemaleri først og fremmest var en hyldest til privatejendommen: "Som en kunstform, var den afledt af princippet om at du er, hvad du har." Oliemaleriet, forklarer han, demonstrerede hvad ejeren allerede besad, og hvorledes han fandt behag I sin livsførelse. Det bekræftede hans følelse af eget værd, forhфjede hans eget syn på sig selv, som han allerede var. Malerierne skildrede de omstændigheder, 
der knyttede til hans eget liv, og udsmykkede det interiør, som faktisk omgav ham, mens reklamens formal er "at gøre tilskueren marginalt utilfreds med sin egen livsmåde"; den tilbyder ham et forbedret alternativ til det, han er. Og Berger understreger det særlige kapitalistiske ved reklamen: "Al reklame er funderet i angst (anxiety). Det hele gøres op i penge, og at tjene penge er at overvinde angst. (...) Penge er livet. (...) I den forstand at penge er tegnet på, og nøglen til, enhver menneskelig mulighed. Muligheden for at bruge penge bliver identisk med muligheden for at leve. If $\varnothing$ lge reklamens legende bliver man ansigtsløs hvis man ikke har penge at spendere. Dem der har den mulighed bliver elsket." 17

\section{Den ny religion}

Reklamen er i dag mindst lige så fremtrangende som religionen var, da pkonomien ikke herskede over alle de menneskelige handlinger. Den er ikke blot et redskab for virksomheder, den er en institution (i ordets sociologiske betydning). Den er en væsentlig socialisationsfaktor. Den sælger ikke forst og fremmest produkter, men den sælger et samfund til dets medlemmer. Den er vores samfunds spejl, som menneskene spejler sig i hver dag, fra de bliver født. Reklamen frembringer sit eget produkt: forbrugeren; den evigt utilfredse og angste forbruger, som fors $\emptyset$ ger at finde sin identitet ind $\mathrm{i}$ den organiserede labyrint af spejle. Hans utilfredsstillelse er nærmest planlagt idet frustationerne er en nødvendighed for det videre forløb: misundelsen skubbes videre. Ved hjelp af misundelsens fornyelse bedøves frustationen samtidigt med at den gøres starkere. Ingen genstand kan leve op til det, reklamen har lovet. Hvordan kan det være sådan? Frustationen skal dyrkes, hvis man skal kunne sælge varesamfundet ogs̊ i morgen. En dynamisk uligevægt vedligeholdes og reducerer livet til spytafsondring. Det, der skal holdes ved lige, er afhængigheden. Reklame er narkotika.

Den ny religion adskiller sig vasentligt fra den tidligere $i$ og med, at det er hedonismen, ikke askesen, som fremmes.

Hvad siger normen? Nyd nu! Nydelsen er vor tids slavers forpligtelse. Nydelsestvang kan forklæde sig som frigørelse. Den traditionelle morale kan fremvises som en hindring. At man gør grin med den, kan bidrage til, at man overser den ny 
normalitets herredømme. Tvangen foreslås som flertallets norm, den fremtræder således ikke som en ordre. Men flertallet ser ikke engang sig selv som flertallet. Hver enkelt er i direkte forbindelse med John Travolta; ikke med alle de hjemmelavede John Travolta kopier, som fylder skolen. Således kan man blive ved med at tro, at man bekæmper normen, năr man er ved at bekræfte den. Man kan mindes den Levis plakat, hvor unge i farverige cowboybukser i fællesskab grinede af en forbipasserende $i$ et mørkt sæt $t \propto j$ ? Det er nu puritaneren, som er marginal. Alle skal nu være med i nydelsens race. Takket være Wrangler er vi ikke alene i vores bukser. P\& trods af vores ensomhed, føler vi, at vi er "in". Saledes er den moderne r $\emptyset$ vballe kun for de cowboy-bukser, som støber den. Den sexualitet, som der opfordres til, skal bruges til forbruget. Enhver skal blive fetichist. Man befries fra puritanismen for at blive lanket til varer. Den seksuelle partner bliver til sidst en vare, og alle de menneskelige dimensioner reduceres til varernes partner.

Reklamen er varesamfundets ideologi i dens reneste form. Magten reduceres til at vare magten til at nyde, og ikke magten til at bestemme over sin tilvarelse. Købekraften er tilladelsen, magten købes med. Den er tilladelse til selv at blive en ting $i$ en tingsliggjort verden. Reklamen tilpasser menneskene til varerne og deres samfund.

Man har pligt til at se glad ud. Ingen må tilstå, at de er ulykkelige i et samfund, hvor man skal føle sig skyldig, năr man ikke er lykkelig. Reklamen er til at for forhindre livsleden $i$ at komme til udtryk. Den er en systematisk eufori. Den instituerer "schein" og skuespilsorden, hvor enhver gør noget for noget andet, hvor magten først og fremmest er noget man bilder de andre ind. Man bilder sig ind, at man har magt, fordi de andre tror på, at man har den. Det er de andres blik, som bekræfter ens eksistens. Reklamen er spejlets totale magtovertagelse. Og selvom mennesker har brug for spejlet, er det ikke givet, at de er så glade for at miste kontrollen over det.

\section{Symbolproduktionen}

Det specifikke for mennesket er symbolproduktionen. Det, som adskiller mennesket fra de andre dyrearter, er, at hele dets psykiske aktivitet, bortset fra nogle fa 
undtagelser, er indirekte eller refleksive, dvs. at enhver handling tolkes. Alt ledsages af refleksive effekter, at forestillinger, fantasmer, ideologier. Samfundet er en symbolsk form som gør tolkningen mulig for de nye medlemmer. De nyankomne, med sa fa instinkter og en sa stor hjerne, færdiggøres ved hjalp af kultur. Barnet tilegner sig de herskende symboler i det samfund det opdrages i.

Man kan saledes ikke angribe reklamen for at vare et spejl. Men man kan analysere hvilken type spejl, der er tale om, og hvilken socialisering det tjener. Ethvert samfund er en symbolsk form, men den organisering af symbolikken, som foregå i reklamen, synes at formindske de kulturelle muligheder, idet den tenderer mod at danne instinktiv adferd. Hvis mennesket er "et politisk dyr", (dvs. selvstyret, autonomt), kan man betragte alt det, som tenderer mod en formindskelse af menneskers tankeevne ved at skabe automatiske handlinger, som "fremmedgørelse". Det man saledes kan angribe reklamen for, er dens tyranni, dvs, dens magtusurpering.

Man kan heller ikke angribe reklamen for at skabe falske behov. ${ }^{18}$ Ethvert samfund etableres gennem skabelsen af behov. Reklamen er vores samfunds mest fremtradende made at skabe behov pa. ${ }^{19}$ Det, reklamen foretager sig, og som man kan kritisere, er, at den tammer begaer og maskerer det som behov. Lad mig - uden at der dermed er givet en forklaring - antyde, at når behovsbegrebet skal dakke både det medf $\phi$ dte og det kulturelle, kan behovsbegrebet ikke bruges til meget andet end til at danne et tågeslør om, hvad der driver mennesker. Behovsbegrebet henviser til det dyriske, ikke til det specifikt menneskelige. Den skjuler, at mennesket selv skaber sine "behov" via samfundet, at samfundet ikke er til for at opfylde forhåndsskabte behov, men tildeler behovene kulturelle funktioner. Det afgørende er saledes ikke, om vi "virkelig" har brug for en genstand. Det afgørende er, at vi er genstand for drifter, drømme, fantasmer, folelser, forventninger, som alle sammen hidrorer fra eller vandrer igennem det symbolske. Sagt pa en anden måde, begaret er kreativt; behovsbegrebet skjuler denne dynamik. Nar man kalder noget, som har med begxret at gøre, for behov, sa indfører man en nødvendighedstro der, hvor friheden kan herske. Behovsbegrebets eneste funktion er at skjule begaret, vores politiske magt, dens egenskaber som kendetegner mennesket, og som skaber historien. 
Reklamen er således ideologi. Ideologi, ikke forstået som det tågeslør, som en klasse producerer for at bevare sin magt over for en anden klasse; men ideologi forstået som en organisering af det samfundsmæssigt imaginære, hvor der i et samfund, der erkender sig selv som selv-skabende, findes principper, som forhindrer alle - men med forskellig styrke - i at påtage sig deres ansvar/frihed fuldt ud.

\section{Reklamen og politikken}

I en tidligere artikel ${ }^{20}$ har jeg skrevet at politikken er folket på opium. Jeg understregede med denne formulering at politikken ikke er noget som kan adskilles fra folket og gives til det som en særlig form for narkotika, men en særlig måde folket organiserer sig selv p§, og hvor "det politiske" - dvs. gøren -subsumeres/underordnes menneskeskabte tvangsmekanismer, som fremkalder apati og ansvarsløshed. Politikken og reklamen har meget til falles.

Når reklamerne gø̆ $\mathrm{grin}$ med politikken, er det for at bekræfte varemes orden. Når politikken angriber reklamen, er det for at kræve en større rationalitet. Kritikken retter sig som regel ikke mod reklamen som ideologi. Det er sandt, at såvel som salgsmiddel som informationsmiddel kan reklamer i mange tilfælde erstattes med langt mere effektive midler. Men hvad kalder man her effektivitet? At reklamen er uproduktiv, at kapitalismen kunne bæres lidt længere, hvis man gik over til tvangsdeling af varerne, som den praktiseres for eksempel i Kina, er meget muligt. Det er især muligt når politikken nu har gjort reklamen til sit sprog. Reklamen kan nu løsrives fra varecirkulationen og fortsat tjene til ideologien et andet sted, eller andre steder...... Eksempelvis er TV og radio reklame, selvom de ikke sælger smør eller gas. Eller gor de? TV og radio er ligesom reklame narkotika og antikommunikation, isæer når reklameteknikkerne hver dag tages til anvendelse, når de prover at sælge sig selv: når man bekæmper sortseerne, når man opfordrer en til at lytte til sin "energist", når man udsender statslige informationer I "Obs", når man prasenterer Næste Uges TV program, når man indleder "Sportslørdag" med "morsomme" situationer.... P4's stil er også meget reklamepræget. I det hele taget er de mange udsendelser om popmusikken udført, som om de var auktioner.

I de lande, hvor reklame-TV er en realitet, er TV-programmerne ligesom smeltet 
sammen. Reklamerne efterligner de andre udsendelser, som selv lever op til reklamerne. I de Forenede Stater produceres der serier, som er planlagte til at indeholde reklamer pa de mest spandende steder. I Frankrig laves der reklamer, som ligner spandingsfilm for at sikre at overforelsesaffektens intensitet binder sig til det reklamerede marke. Produkter gøres til helte, som bekxmper angst. Muppetfigurerne samt kendte TV-speakere salges til reklamebranchen. Reklamerne blandes med korte underholdende tegneserier. De nye Anders-And'er er i selve deres konception tankte bade for borneudsendelserne og for den handelsmassige udnyttelse af figuren. Videomaskinerne konkurrerer med supermarkederne om bornepasningen (der findes fleres og flere som ikke har andet som "frelles" aktivitet med deres bøm end at køre, købe, eller glo). Pa skærmen skal der ske noget, fordi der ikke sker noget på stolen. Bevagelsestegn forherliges for at skjule passiviteten. Informationstegn (informationer som varer) fylder hjernen og bedøver. Alt forbruges; alle former for iscenesattelse efterligner en anden; iscenesattelsen af forbruget og forbruget af isceneszttelsen vil snart smelte fuldstandigt sammen. Dette er langt alvorligere end den skjulte reklame i sportsudsendelser.

At reklamerne i TV betragtes som underholdning, at de i mange tilf alde er kunstvarker lavet af kreative mennesker, kan ikke vare en undskyldning, tvartimod. Kunsten kan ikke vare tjent med de begransninger, markedsforingen satter. Opfordringen til legen kan vare opfordring til at glemme alt andet end forbrug.

Man kan finde reklamer, hvor der gøres grin med reklamen, men selvf $\emptyset$ lgelig ikke med varen, og endnu mindre med annoncøren. Man gør blot til grin for at f\& budskabet til at trange ind. Hvis reklamen kan lave parodier af sig selv, er det ford, den er fuldt institueret. Annoncorerne reklamerer med deres selv med fuld alvor. De skriver bøger om deres erhverv og deres personlighed, og salger deres image så godt, de kan.

Politikerne gør det samme. De salges som sabe. Det sprog de anvender er det samme. De galluperer hver maned og bygger deres image ved hjalp af reklameteknikker. 


\section{Reklamens retorik}

Den form for retorik, som reklamen støtter, og som har invaderet politikken og medierne, kendetegnes ved bestemte egenskaber, særegenheder.

Reklamerne indeholder tit tautologier. Tautologien foregiver at forklare tingen/varen ved at gentage ordet. $\mathrm{P}\{$ den måde udelukkes enhver analyse af det, der tales om. Når man siger "Danmark er Danmark" forbyder man ethvert spørgsmal om, hvad Danmark er for noget. Det antydes (også), at der er tale om noget evident, som kun idioter kan stille spørgsmål om. Der forsøges også at samle folk, som ganske vist har forskellige opfattelser af hvad Danmark er for noget, men som kan identificere sig med den magiske formulering. I tautologien bliver alle tegn reduceret til et eneste: logoen (mærkatet). (Danmark, det ved man hvad er ...).

De mange metaforer, metonymier og synekdoker bruges til at bortlede den kritiske sans. Hyperbolen ødelagger hverdagssproget. Hvad er endnu mere hvidt end hvidt? Antitesen forsøger at overføre begejstringen for udtryksmåden til begejstringen for varen. Litoter bruges som regel for at smigre dem, som lader sig bilde noget ind.

I reklamerne dyrkes en "bi-tingsretorik", hvor det underordnede pustes op til at dakke hele virkeligheden. Billedernes konnotationer bliver altid forenet med denotationen 21 for at de førstes realisme kan sælge de andres værdier. Salledes sælger man både produktet og en livsmåde.

Reklamens retorik forvirrer og tenderer mod at forhindre enhver analyse. Virkeligheden bliver last fast i skinnet/"schein". Produkternes tilblivelsesprocesser, anvendelsesmuligheder og betydning for vores liv og de andres liv bliver svært at erkende. Reklamerne gør det kun muligt at se, forstålelse er farlig.

\section{Et nyt sandhedsbegreb}

I reklamen interesserer man sig ikke for om det, man siger, er sandt, men om det er trovardigt. At vise er at bevise. I reklamerne overbeviser man ved at fremvise, man nøjes med at gøre som om, man er ved at forklare. Bare det ser ud til, at man 
er I gang med at bevise, er bevis nok.

Reklamen er efterhånden kunsten om at lade tingene blive virkelige ved blot at erklære, at de er det (selffulfilling prophecy). Den behøver ingen forudgånde virkelighed, begivenhed eller genstand; den beh $\phi$ ver en senere bekræftelse. Den gør genstanden til en pseudo-begivenhed, som bliver virkelig ved forbrugernes tilslutning til diskursen.

Oprindelig skulle reklamen bygge på den eksisterende kultur, og man finder stadig mange henvisninger til, hvad man har læert i skolen eller i hjemmet. En bamse giver andre associationer end en høj hat eller end en vikingehjelm. Men idet reklamen efterhånden overtager en hel del af socialiseringen kan den nøjes med blot at henvise til sig selv. 22

I Sepstrups bog fremstilles reklamen som varende bedragerisk. Og det er reklamen netop ikke. Reklamen er os ikke utro. Den er hverken sand eller falsk. "Vi forestiller os, at reklamebranchen har bragt flere usandheder ind i verden. I virkeligheden har den omformet selve vort sandhedsbegreb." ${ }^{23}$ vi vil let kunne skaffe reklamens onder ud af verden, hvis de kun skyldtes uhæderlighed. De egentlige problemer er af ganske anden - i visse henseender diametralt modsat karakter. Reklamen forplumrer ikke vore erfaringer, fordi reklamefolkene lyver, men tværtimod fordi de taler sandhed. De tågeslør, den lægger, er ikke et resultat af løgnagtighed, men af dens specielle form for sanddruhed." 24 Det reklamen siger, er ikke falsk. Den har sin egen logik og kohærens, som ikke stammer fra en eller anden virkelighed, men stammer fra koden selv, som nu strukturerer virkeligheden.

\section{En moral for beskuende slaver}

Ligesom man ikke kan forstă fascismen og nazismen, hvis man blot henviser til tyrannens magt og glemmer at analysere accepten, kan man heller ikke forsta reklamens magt ved blot at henvise til reklamefolkenes eller de multinationale selskabers gradighed.

Ligesom moden er hinsides det kønne og det grimme, den politiske fornuft, det 
gode og det onde, og ligesom vores varer er hinsides det nødvendige behov eller det kunstige behov - er reklamen hinsides det sande og det falske.

Reklamen er et nyt sprog, det herskende sprog i vores massesamfund. Et sprog som ikke ernarer sig af objektiv virkelighed, men af koder og modeller, et sprog som hverken ernærer sig af henvisninger eller af sandheder, men af umiddelbar forførelse. Det ernarer sig af kodebegær. Reklamen er vor tids religion, den er en moral for beskuende slaver, en moral, hvor der ikke tales om idealer, men blot vises billeder, en religion, hvor beskuelsen nærmer sig ekstasen.

Forførelsesintensiteten kan stamme fra denne hyperkohærens, som karakteriserer koden: man føles fri for virkeligheds tvang, begaret er nu tvangsfrit.

Det moderne massemenneske begarer koden, og det er jo "menneskeligt." Ja netop! Sproget er til for vores orientering, og ethvert samfund instituerer sig, ved at etablere en kode, som giver verden mening. Men problemet med reklamen, det moderne samfunds sprog, er, at den blot er en form uden mening. Den er et medie, som er sit eget budskab (Marshall McLuhan). Signifiant (det akustiske billede) løsriver sig fra signifié (betydningen). Koden er nu selv den eneste virkelighed, den eneste referent for koden.

Dette sprog forudsætter ingen forudgående virkelighed, det skaber en senere bekræftelse ved hiælp af det tegn, den sender. Denne diskurs bekræftes ved massernes konsensus, som den selv skaber. Det er det rene magi: tegnet hersker over virkeligheden. Virkeligheden er så at sige sat på hovedet.

\section{Det tomme sprogs triumf}

I dette sprog er det, Roman Jakobson kaldte den "konnotative funktion", det afgørende. Måden, der tales på, gør det, man taler om, underordnet. Indholdet er blot et alibi for forførelsen. Sepstrup fortaller os at reklame pa tysk skrives Werben, han burde have gjort os opmærksomme på, at Werben oprindeligt stod for "at fri". 
Reklamen er forførelse på en særlig måde. Den sælger ikke produktet. Den sælger ikke sig selv, men forførelsen. Propagandaen overbeviser mindre og mindre, idet den slär sit eget indhold ihjel med alle dens modsigende budskaber. Den repræsenterer sin egen funktion, og det betyder, at den kommer til at repræsentere sin egen repræsentativitet i stedet for at repræsentere det, den hævder at være udtryk for. Det samme galder reklamen: den sælger ikke, den er koden. Jean Baudrillard skriver, at propagandaens og reklamens strategi er en generaliseret social integrationsstrategi: "der er tale om en iscenesættelse af ethvert menneskeligt forhold i overensstemmelse med den kode som de påbyder, en generaliseret social-kontrols strategi af en befalende og forf $\phi$ rende type, abstrakt og skuespilagtig". 25

Om folk tror på reklamernes påstand eller ej, er underordnet, blot de taler reklamens sprog. Om reklamefolk er sig det, de gør, bevidst eller ej, betyder heller ikke så meget. Der fandtes også præster med og uden tro, der fandtes endda nogle, som tænkte over deres funktion. Det væsentlige er, at reklamefolkene er myteoperatører, hvis arbejde består i at skabe overbevisende budskaber, som hverken er sande eller falske.

I vores moderne samfund oplever vi den store opsugning af alle de mulige udtryksformer i reklamens form. Det er det tomme sprogs triumf, hvor de enkelte forskellige indhold ophaves. I dette matte univers, der er gjort ufølsomt, følelsesløst og apatisk, bliver enhver isoleret i sin inerti. Big brother is in us.

Varesamfundet er nået så langt, at der ikke findes forskelle mellem det økonomiske og det politiske, for overalt hersker den samme kode/sprog. Nu er det det samfundsmæssige selv, som sælger sit varemærke.

Man kan ikke skelne mellem reklamen og resten. Formen omgiver og omformer os.

Reklamen er det sprog, den religion, som hersker i et samfund, hvor man ikke kan adskille økonomi og politik, fordi den "politiske фkonomi" hersker i det. 


\section{At bekrafte diskursen}

Konkluderende kan siges, at bogen svigter i sin analyse af reklame-fænomenet på grund af en for stor respekt for merc.'ernes verden, dvs. pa grund af et manglende kendskab til sociologisk metode. Man vil derfor ikke undre sig over, at så mange vigtige sociologers værker om reklamen ikke findes i bibliografien.

Det er jo desværre tvivlsomt om det lykkes at forhindre TV-reklamer i at overtage vore børns socialisering, men det er nok vigtigt at give de fleste muligheden for kritisk at se på reklamerne, især de unge.

Var det ikke Marshall McLuhan som gjorde opmærksom på, at "enhver reklame som der lægges bevidst mærke til er komisk"? 26

Det, jeg kritiserer Sepstrups bog for, er at den ikke formidler nok forståelse på grund af dens forankring i en bestemt metode. Den forbliver for meget på fjendens grund. Ikke desto mindre giver den mange gode informationer og mange gode forslag til at bekæmpe reklamen med. Men hvis den henvender sig til gymnasieelever, synes jeg, det er en skam, at de skal have det indtryk, at man skal analysere reklamen, ligesom de har fået at vide, at man skulle forstå den økonomiske politik ved hjelp af statistisk materiale, matematiske modeller og politisk ideologi, dvs, at eleverne skal blive bekræftet i opfattelsen af, at økonomien forklarer alt, når analysen af reklamen kunne have hjulpet dem til at forsta, at det netop ikke er tilfældet, men at det er фkonomien som vores nuværende my te, der skal forklares. 


\section{Noter}

1. Hans Reitzels forlag, København 1982, 204 sider, 132,50 d.kr.

2. Ibid., s. 10.

3. Ibid., s. 157.

4. Ibid., s. 50.

5. Ibid., s. 177.

6. Ibid. samme sted.

7. Ibid., s. 36-46, 71-72, 84, 113 og 120-126.

8. In Revue Française de Sociologie, Volume X, p. 279-311.

9. I Randers Amtsavis d. 2. februar 1982.

10. d. 8. januar 1982.

11. d. 9. januar 1982.

12. Jvf. s. $27-28$ og 56 i Sepstrups bog.

13. Jvf. s. 14, 27 og 63 i Sepstrups bog.

14. Offentlighedens form kan muliggøre en ny produktionsform; produktionen behøver ikke at være det væsentligste i et samfund.

15. Christopher Lasch: The Culture of Narcissism. Abacus. London 1980, p. 139. (Norton 1979). Findes nu pa dansk. (Kapitel 4).

16. John Berger: Ways of Seeing. Penguin. Harmondsworth, 1972, p. 134. 
17. Ibid., p. 139-143.

18. Jvf. s. $30,32,34$ og 53 i Sepstrups bog.

19. Sepstrup "formoder", at reklamen spiller en rolle for alle menneskers opfattelse af, hvad der er vigtigt, og hvad der er normalt. Det er, som om hans tro pa kvantitative analyser forbyder ham at turde sige mere. (s, 123).

20. Dominique Bouchet: "Man bliver aldrig færdig med at miste sin frihed Fortænkt om politik." in: Antipolitik. Hinsides al statskunst. En antologi redigeret af Carsten Juhl og Paul Smith. Forlag Afveje. Århus 1981, p. 18-23.

21. Denotationen er den konkrete virkelighed et tegn refererer til. Konnotationerne er bibetydningerne, som associeres til tegnet.

22. En illustration på dette findes på side $168 \mathrm{i}$ bogen: "Jeg drikker Jägermeister, fordi jeg kan få mændene til at læse annoncen", siger en pige, hvis nøgne bryster synes at være falske jägermeisterflasker.

23. Daniel Boorstin: Den syntetiske verden "The Image", Gyldendals Uglebøger 1968. USA 1961. pr. 220.

24. Ibid., p. 228.

25. in: Encyclopædia Universalis Vol XVII. Paris 1978. p. 394.

26. Marshall McLuhan: Understanding Media, Abacus, London 1973. p. 243. USA 1954. S. 253 i den danske oversættelse hos Gyldendal 1967.

Dominique Bouchet er lektor i sociologi

ved Institut for Nationaløkonomi

og Sociologi ved Odense Universitet 